\title{
CRUSTAL INHOMOGENEITIES OF BRANSFIELD STRAIT (WEST ANTARCTICA). NEW GEOPHYSICAL DATA
}

\author{
S. Levashov' ${ }^{1}$ I. Korchagin ${ }^{2}$, Yu. Kozlenko², V. Solovyov ${ }^{2}$ \\ ${ }^{1}$ Institute of applied problems of Ecology, Geophysics and Geochemistry, SLEVASHOV@MAIL.RU \\ ${ }^{2}$ Institute of Geophysics of Ukraine National Academy of Science, e-mail valera@igph.kiev.ua
}

\begin{abstract}
The Ukrainian Antarctic expeditions provided new geophysical data for many West Antarctica bottom structures. Gravity, magnetic- and electromagnetic surveys near the Antarctic Peninsula enabled to specify the age of the formation of some blocks, separate local crustal inhomogeneities of Bransfield Strait and continental margin of Antarctica. The similar results obtained by three different methods assure the notable magmatic activity of Bransfield Trough that forms in the conditions of structural transformations and rifting processes migrating NE-SW war along Bransfield Strait. It is quite probable that this area is dominated by diffusion tension process but not by the expansion of a mid-oceanic ridge in a back of a volcanic arc.
\end{abstract}

Реферат. Отримано нові дані про розподіл геофізичних полів для тектонічних структур дна Західної Антарктики, які дозволили виділити локальні неоднорідності земної кори протоки Брансфілд. Виявлено великий вплив тектонічних факторів на формування неоднорідної осадової товщі. Показано, що розподіл аномальних магнітозбурюючих тіл має такий саме характер, як і розташування силлів, визначених методом вертикального електрорезонансного зондування.

Реферат. Получены новые данные о распределении геофизических полей для тектонических структур дна Западной Антарктики, которые позволили выделить локальные неоднородности земной коры пролива Брансфилд. Выявлено большое влияние тектонических факторов на формирование неоднородной осадочной толщи и основных характеристик глубинных разрезов земной коры. Распределение аномальных магнитовозмущающих тел в верхних частях аномальной коры в значительной мере отражает наличие силлов и отдельных интрузий, выделенных по данным вертикального электрорезонансного зондирования.

\section{Introduction}

The tectonic evolution of Bransfield Strait region is related with the evolution of the ambient areas, in particular the Sea of Scotia, southern margins of South America and the Antarctic Plate [1-4]. The structural position of the Strait in the complicated of the interaction of different-age formations of this region creates the main features of its deep structure. The trans-arc Bransfield Trough with the Bransfield Platform is a Cenozoic basin situated in the back of the South-Shetland Isles and the Shetland Trough. The chronology of Bransfield Strait extension is probably associated with the model of collision of the ridge-trough type [2,3]. An argument supporting the assumption of the existence of a subduction with trans-arc extension is that the Strait Trough has the same length as the trough of the South Shetland Isles.

It may be assumed that the central part of Bransfield Strait in the present state of geodynamic evolution greatly resembles the regional extension areas where whole systems of tectonic disturbances due to features of the interaction of plates that favored tectonic processes and highly developed Cenozoic volcanism of different types. Therefore this region is interesting not only from viewpoint of studying processes of multiphase expansion in Mesozoic but also as an area of young tectonogeodynamic processes of 2,5-4,0 my age accompanied by the formation of many volcanic uplifts and ridges composed of tholeiites and alkali basalts. 
Seismic studies. The deep lithosphere structure of the Strait was studied by use of refracted and overcritical reflected waves during expeditions made by the Polish Academy of Sciences in 1979-1991 years (fig. 1). The seismic data reflect a complicated geological structure and tectonics, a notable change of the physical properties of the Earth's crust of this region with depth and laterally [5-9].

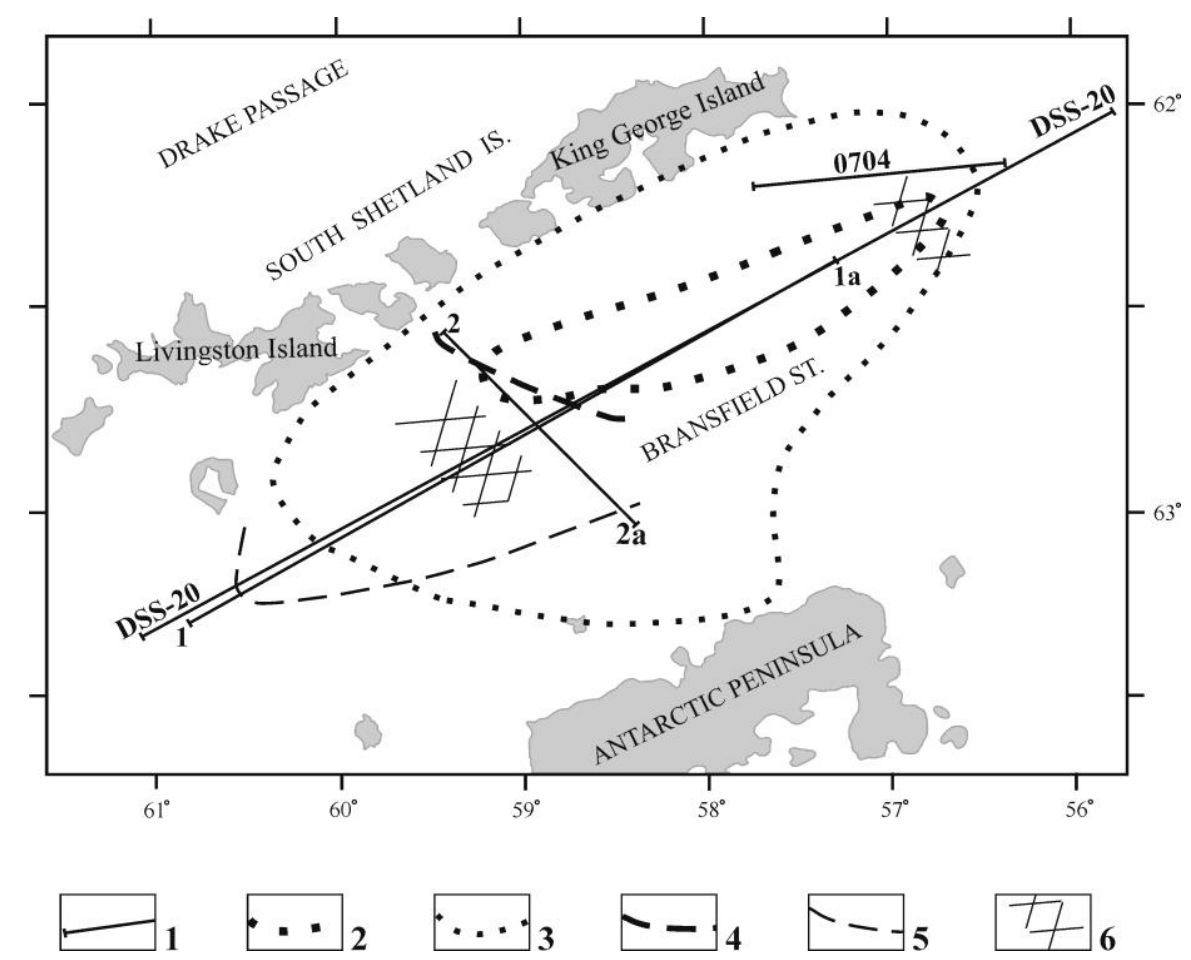

Fig. 1. Geophysical studies in Bransfield Strait: 1- geophysical profiles; 2 - position of the central part (core) of the block of abnormally high velocity (AHVB) by seismic data [5]; 3 - limit of AHVB expansion (peripheral part) by seismic data [5]; 4 - boundary of zones I-II by VERS data; 5 - boundary of zones II-III by VERS data; 6 - disturbance zones by seismic data [5].

Fig.2 shows the crustal layers distribution along Bransfield Strait over the DSS-20 profile. The water mass is underlain by young slightly consolidated sediments with seismic wave velocities of $1,9-2,9 \mathrm{~km} / \mathrm{s}$. The next two horizons with velocities of $3,5 \mathrm{~km} / \mathrm{s}$ and $4,0 \mathrm{~km} / \mathrm{s}$ include some old and more consolidated sediments and lava flows. The sediments are underlain by rocks with velocities of 5,2-5,8 km/s that are typical for acid metamorphic and crystalline rocks. They lie on a crystalline basement with velocities of $6,4-6,9 \mathrm{~km} / \mathrm{s}$.

At depths from $10-15 \mathrm{~km}$ to $25 \mathrm{~km}$ an abnormally high velocity block (AHVB) with $\mathrm{Vp}=7,4 \mathrm{~km} / \mathrm{s}$ in the upper part of the body and a high vertical velocity gradient was detected. According to the seismic data, the general structure of the AHVB resembles a mushroom with a rather thin (yet not round but stretched along the trough) that joins the mantle and a broader bonnet of the peripheral part (fig.2). Considering the AHVB form, it may be assume that this body formed due to magmatic activity, the arrival of pyroclastic material from the upper mantle.

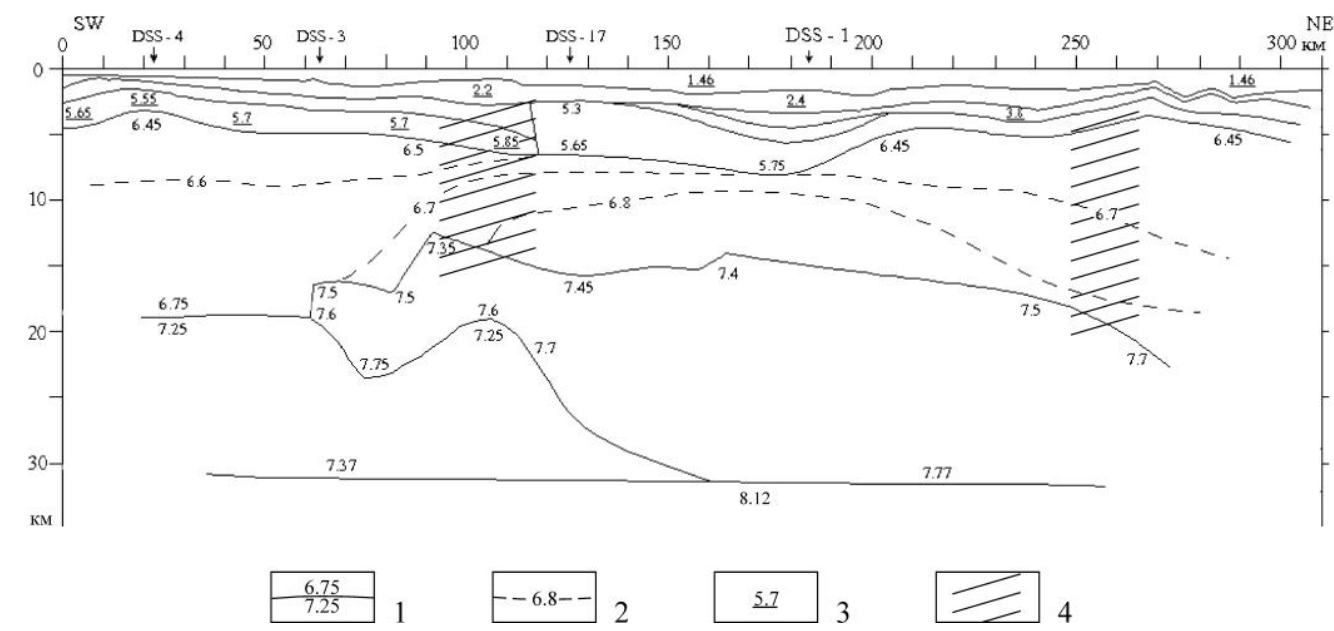

Fig. 2. Seismic structure of Bransfield Strait along the profile DSS-20 [1]; 1 - boundaries with velocity jump, $\mathrm{km} / \mathrm{s} ; 2$ - isolines of seismic velocities, $\mathrm{km} / \mathrm{s} ; 3$ - mean formational velocities, $\mathrm{km} / \mathrm{s} ; 4$ - disturbance zones. The profile position is shown on fig. 1 . 
Along the profile DSS-20 two disturbance zones have been detected, one on the PP 100-115km near the NE end of the Livingston Island; another -on the PP 250-260 km beside the NE end of the King-George Island (fig.1). The information available is insufficient to answer the question of the origin of these zones. It may be associated with transform faults beginning at the Drake Plate.

Magnetometric studies. Numerous magnetometric observations in the Antarctic Peninsula region were enabled by the aeromagnetic survey whose results were used to compile a generalized sketched magnetic field map [3, 7, 8].

The magnetic data define the trough axial zone as a prolate positive anomaly where the magnetic field anomaly values reach $+400 \mathrm{nT}$. On both sides of the positive anomaly bands of negative anomalies attaining values above -400 nT are observed.

The data obtained by marine Antarctic expeditions in 1997-1998 years [9, 10] made more accurate the results of the aeromagnetic measurements. According to these data, the magnetic anomalies have spike forms in the eastern Bransfield Strait near the coast of the King-George Island (profile 0704, fig.1) Their intensity exceeds +1200 nT (Fig.3). Moreover the short-period anomalies are superimposed on the long wavelength magnetic field component cf. $32 \mathrm{~km}$ long. Long wavelength component extreme are marked on PP 18 (-310 nT), 50 (500 nT) and 83 (-500 nT).

At the Institute of Geophysics NAS of Ukraine an effective program complex of magnetometric observation data interpretation [10] was worked out which was used to model the magnetic anomaly sources along the profile. The program selected in automated regime the parameters of magnetic bodies that satisfy the observed field. As a result, the forms and positions of bodies changed (fig.3). They assumed not vertical (as in the zero approximation model) but horizontal orientation, i.e. the general strike of the center of Bransfield Trough to its edge. The depth of the occurrence of the centers of all three large bodies appeared to be 4,7, 7,8 and 11,4 km, the depth level of the magnetic bodies decreasing regularly from Bransfield Trough center to the periphery, too. The declination angle of the line passing through the centers of the bodies is $7^{\circ}$.

The vertical electric-resonance sounding method studies. The fact that the inhomogeneities are not confined to the lower crust but are also seen in the upper layers was established in 2004 by use of a modern instrumentation with the vertical electric-resonance sounding (VERS) method [6] along the profiles in Bransfield Strait (fig.1).

\section{The Antarctic Peninsula region}

a)

$62^{\circ} 13.55^{\prime}$ S., $57^{\circ} 42.02^{\prime} \mathrm{W}$.

$62^{\circ} 08.36^{\prime}$ S., $56^{\circ} 05.84^{\prime} \mathrm{W}$
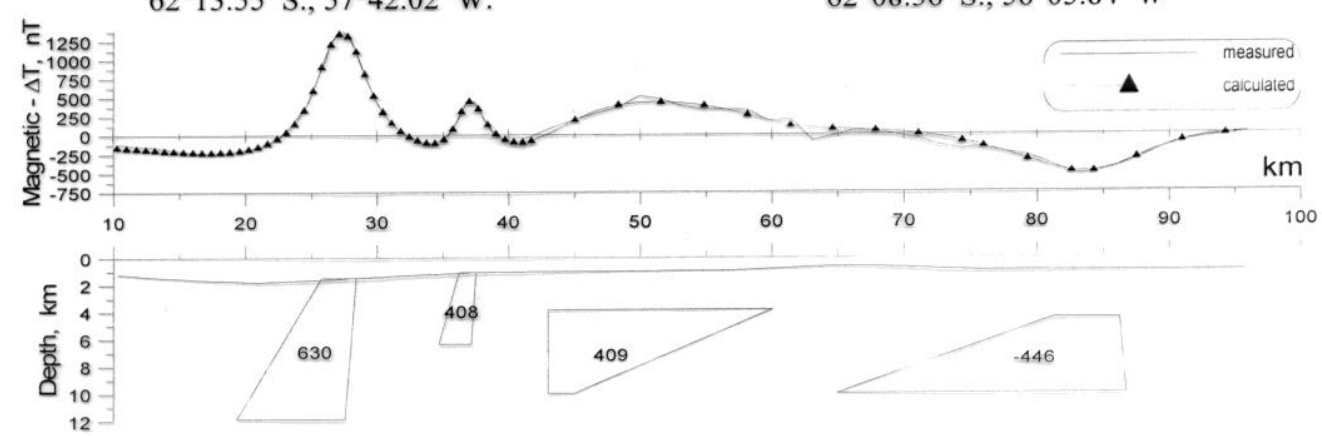

b)

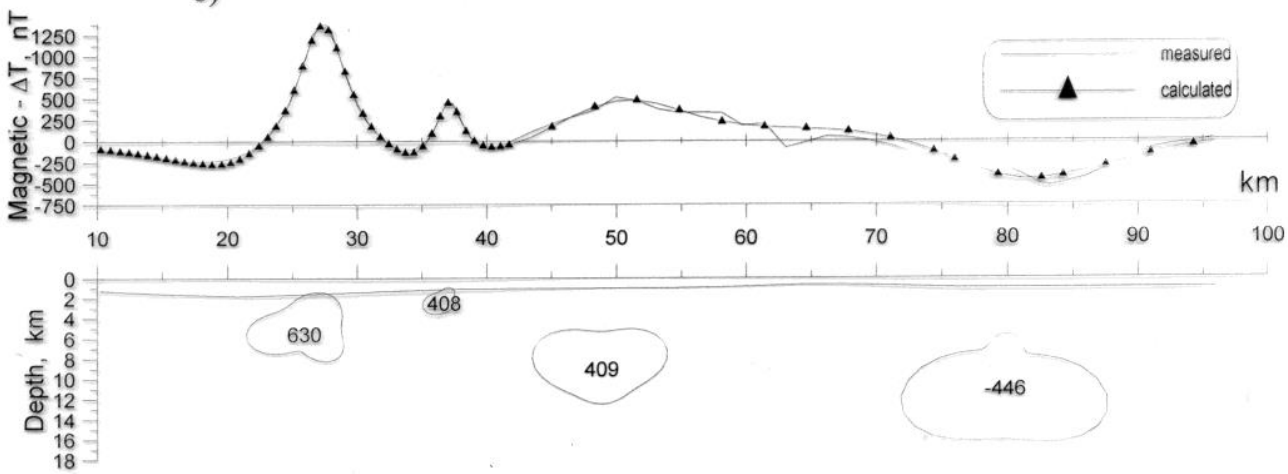

Fig. 3. Results of magnetic field modeling along the profile 0704; a - observed magnetic field; $b$ - model anomaly. The numbers show the magnetization intensity values for bodies (in $\mathrm{A} / \mathrm{m}$ ). The profile position is shown on fig. 1 .

An upper crust section to a depth of $6000 \mathrm{~m}$ set up using VERS results obtained along the Bransfield Strait (profile 1-1a) is presented (fig.4).

A clear-cut feature of this section is the essentially different-character of the lateral geoelectrical resistance distribution within the layer third from the floor surface (with $\mathrm{Vp}=5,2-5,8 \mathrm{~km} / \mathrm{s}$ on the seismic sections) that belongs to the crystalline basement. The parameters obtained suggest subdivision of the profile into three zones.

A similar characteristic of the upper consolidated crust subdivided into three zones is marked on the profile 2-2a across the Bransfield Strait (fig. 5). Beside the trough edge on the side of the South Shetland Isles the main layer is that of the low geoelectrical resistance (zone III), on the side of the Antarctic Peninsula that of the normal geoelectrical 
resistance (zone I), and the central profile part alternates all three types (zone II). In this section the layers lay sub horizontally and slightly $\left(1-3^{\circ}\right)$ dipping to both sides.

The boundaries between the zones separated by the VERS data are shown in fig.1. It appears that the boundary between the zones II and III almost completely coincides with that of the core of the abnormally high velocity block by seismic data. The boundary between the zones II and I lies near the boundary of the AHVB expansion though it does not coincide with it.

The conclusions that may be drawn from the VERS data are as follows: the normal geoelectrical resistance layer represents unaltered rocks of the upper part of the crystalline basement

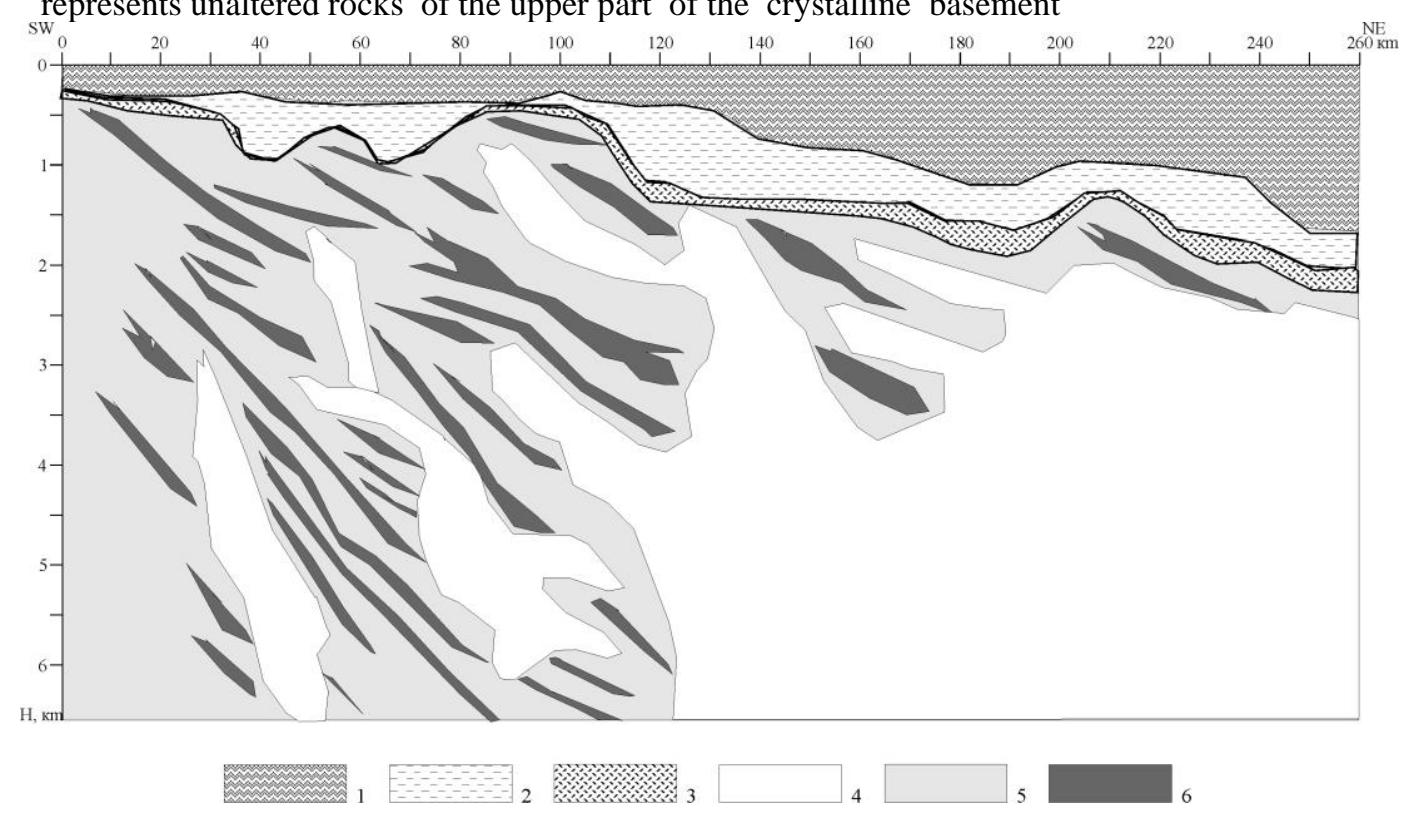

Fig. 4. Vertical section along the profile 1-1a in Bransfield Strait by VERS data: 1 - water; 2 - nonconsolidated sediments; 3 - compacted sediments; 4 - low geoelectrical resistance blocks; 5 - normal electrical resistance blocks; 6 high geoelectrical resistance blocks. The profile position is shown on fig.1.

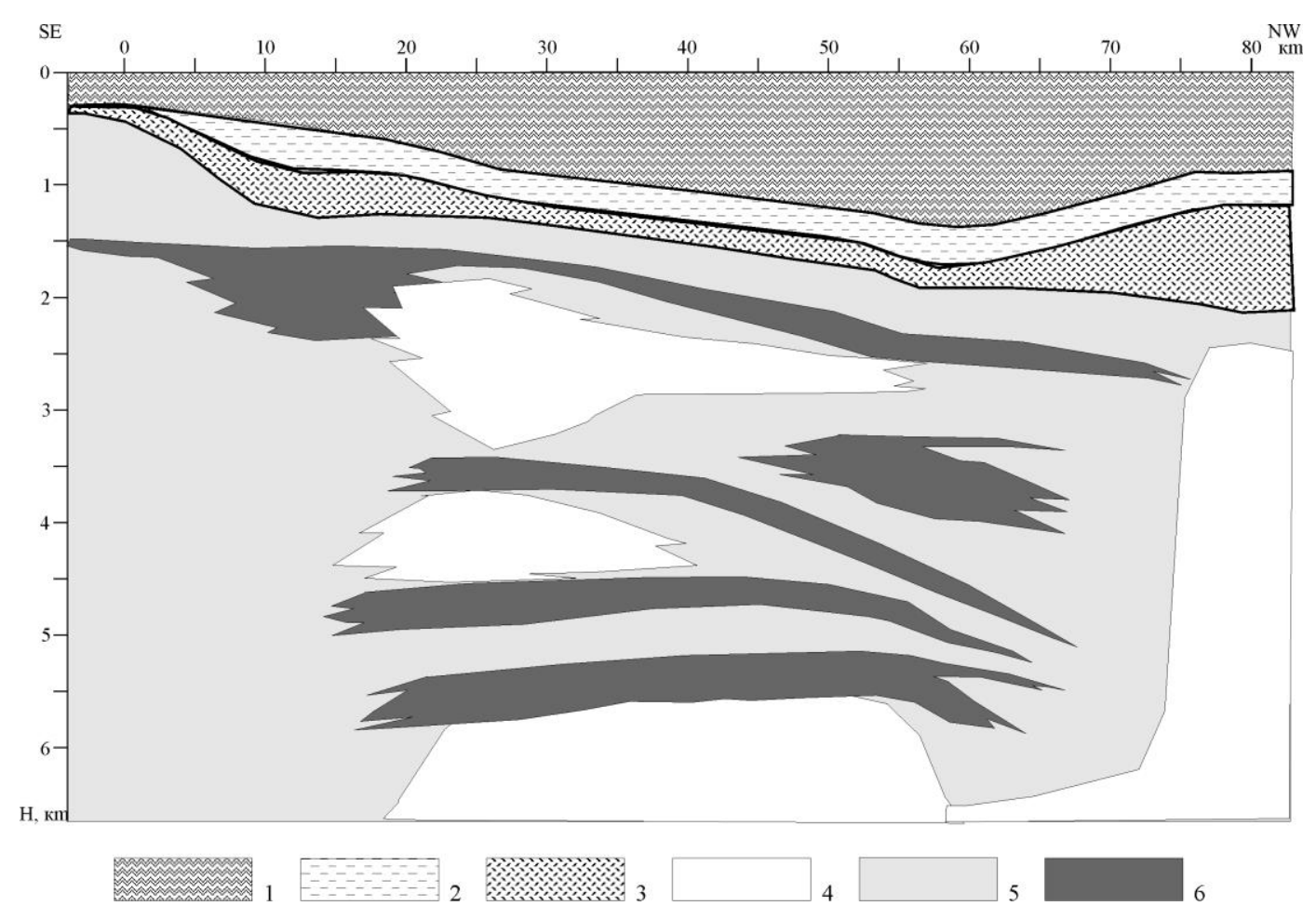

Fig. 5. Vertical VERS section along the profile 2-2a through Bransfield Strait. The legend is given in fig.4. The profile position is shown on fig.1.

outside the abnormally high velocity block; the high geoelectrical resistance marks intrusion of magmatic sills over the peripheral parts of the AHVB; the low geoelectrical resistance is characteristic of the rocks changed under the effect of magmatic (most probably hydrothermal) activity over the AHVB core. As to the possibility of the existence of sills in the Bransfield Strait, the upper crust seismic data interpretation shows that lavas and sediments on the sides of the strait are internally stratified magmatic activity favors the appearance of dikes and sills within the sediments [7]. The effect of the abnormally high velocity block on the upper horizons is doubtless as shown by high upward curvature of seismic velocity isolines over the AHVB in the middle crust (fig. 2). 
Conclusions. Combined analysis of geophysical data of Bransfield Strait in West Antarctica has been made. The similar results obtained by three different methods suggest a notable magmatic dynamism of Bransfield Trough forming in the conditions of structural transformations migrating NE-SW along Bransfield Strait. Seismic results do not confirm unambiguously the development of active spreading and the presence of a crust of oceanic type in this part of the Strait. It is quite probable that this area is dominated by diffusion tension process but not by the expansion of a mid-oceanic ridge in a back of the volcanic arc.

\section{References}

1. Barker D.H.N., Austin J.A. Rift propagation, detachment faulting and associated magnetism in Bransfield Strait, Antarctic Peninsula // Journal of Geophysical Research. $\quad$ - 1998 . $\quad 103 \quad$ (B10). P. 24,017-24,043.

2. Barker P.F. and Lawver L.A. South American-Antarctic plate motion over the past $50 \mathrm{Myr}$, and the evolution of the South American-Antarctic Ridge // Geophysical Journal. - 1988. - 94. - P. 377-386.

3. Robert D. Larter and Peter F. Barker. Effects of Ridge Crest-Trench Interaction on Antarctic-Phoenix Spreading: Forces on a Young Subducting Plate // Journal of Geophysical Research. - 1991. - v. 96, № B12. - P. 19,583-19,607.

4. Ashcroft W.A. Crustal structure of the South Shetland Islands and the Bransfield Strait. -British Antarctic Survey Scientific Reports. - 1972. - 66. - P. 1-43.

5. Grad M., Gutterch A., Janik T. Seismic structure of the lithosphere across the zone of subduced Drake Plate under the Antarctic Plate, West Antarctica // Geophis. J. Int. - 1993. - v. 115.- P. 568-600.

6. Левашов С.П., Якимчук М.А., Корчагін І.М., Піщаний Ю.М. Метод електрорезонансного зондування та його можливості при проведенні комплексних геолого-геофізичних досліджень // Геоінформатика. - 2003. - № 1. - С. 1520.

7. Veit Andreas. Volcanology and geochemistry of Pliocene to Recent volcanics on both sides of the Bransfield Strait (West Antarctica). - 2002. - 179 p.

8. Lodolo E., Coren F., Shreider A.and Giulio Ceccone. Geophysical Evidense of a Relict Oceanic Crust in the Southwestern Scotia Sea // Marine Geophysical Research. - 1997. - 19. - P. 439- 450.

9. Бахмутов В.Г., Козленко Ю.В., Корчагин И.Н и др. Геофизические исследования в украинских морских антарктических экспедициях (по материалам 60-го и 61-го рейсов НИС «Эрнст Кренкель»). Киев: Ин-т геофизики НАН Украины. - 2001. - 323 с. - Деп. в ГНТБ Украины 9.04.2001. - № 70-Ук2001.

10. Старостенко В.И., Гросс С.С., Коболев В.П.и др. Новые технологии при проведении гидромагнитных исследований в морских акваториях: методика измерений, алгоритмы обработки, практические результаты // Геофізичний журнал. - 2003. - 25, № 2. - С. 70-89. 